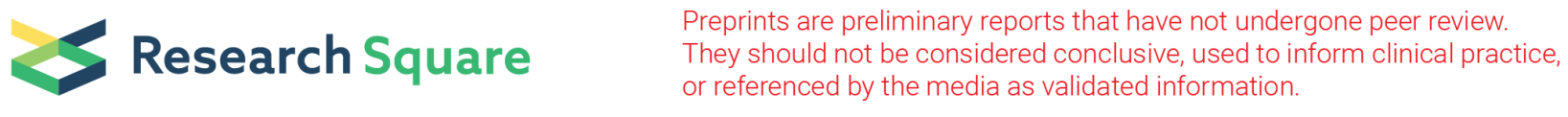

\title{
Spatial Distribution, Source Discrimination, and Health Risk Assessment of Arsenic and Fluoride in Drinking Water Around Brick Kilns of Vehari, Punjab, Pakistan.
}

\author{
Muhammad Akram \\ COMSATS University Islamabad \\ Rukhsar Fatima \\ COMSATS University Islamabad - Vehari Campus \\ Atta Rasool ( $\sim$ drattarasool@gmail.com) \\ COMSATS University Islamabad \\ Allah Wasaya \\ BZU: Bahauddin Zakariya University
}

\section{Research Article}

Keywords: Arsenic, Fluoride, Principal component analysis, Atomic absorption spectrophotometer, Cancer risk, Water intake rate

Posted Date: September 8th, 2021

DOI: https://doi.org/10.21203/rs.3.rs-782561/v1

License: (c) (i) This work is licensed under a Creative Commons Attribution 4.0 International License. Read Full License 


\section{Abstract}

Water is very important to maintaining life on earth. Fluoride and Arsenic pollution in groundwater is an emerging issue in the world. Atomic absorption spectrometry was used to measure total arsenic, while ion chromatography was used to determine fluoride. The present study was conducted for the health risk assessment of fluoride and arsenic in groundwater around brick kilns. 58 samples of groundwater were collected from district Vehari Punjab and were analyzed for arsenic concentration ranges from 0.330 to $11.120 \mu \mathrm{g} / \mathrm{L}$, higher than the WHO recommended permissible level of arsenic in drinking water $(10 \mu \mathrm{g} / \mathrm{L})$. The mean value of fluoride in the water supply for drinking is $2.599 \mathrm{mg} / \mathrm{L}$ as its concentration ranges are 0.680 to $9.690 \mathrm{mg} / \mathrm{L}$ respectively. All the values of fluoride in drinking water were higher than the permissible limit according to WHO standard $1.5 \mathrm{mg} / \mathrm{L}$. The spatial distribution of arsenic and fluoride in groundwater indicates their direct contamination with rock weathering, coal burning, and the use of cheap fuel in brick kilns. The estimated average dose (ADD), hazards quotient (HQ), as well as cancer risk (CR), were computed using statistical formulae to determine the health risks of arsenic and fluoride. The hazard quotient (HQ) values of As and $\mathrm{F}^{-}$in this research area were higher protection and safe limits $(\mathrm{HQ}>1)$, having health risks to the people in this region, caused by brick kilns. Statistical parameters correlation and cluster analysis were used to determining possible contaminant sources in the study area.

\section{Research Highlights}

- As and F concentrations surpassed WHO limits for drinking water guidelines

- As and F pose serious risks to human health of local peoples

- Both Anthropogenic and geogenic activities contribute to water contamination

\section{Introduction}

Water is the basic essential for living. It plays an important role in the environment and human life. Fluoride (F) and arsenic (As) are impotent elements that cause health problems in people living around the world. F and As contamination in the groundwater due to anthropogenic activities and natural sources. These activities are weathering and erosion of rocks, brick kilns, biological activities, wood preservatives usage, paints, metals, soaps, fertilizers, different herbicides, pesticides, dyes, and drugs ( Farooqi et al. 2009; Rasool et al. 2016). But brick kilns are the main source of fluoride and arsenic in groundwater. Low-quality fuel is used in brick kilns for instance; oily sludge, coal, rubber tires, wasted oil, wood, etc. (Khalid and Mansab 2015). F concentration of more than 1.5mg/L in drinking water can cause skeletal fluorosis, kidney stones, decrease birth rates, tooth decay, and bone weakness in humans ( Guo et al. 2007; Khalid and Mansab 2015). While As concentration of more than $10 \mu \mathrm{g} / \mathrm{L}$ in drinking water can cause hepatitis, skin, and lung cancer respectively (Khalid 2019).

Arsenic contamination in groundwater is extending from east to west (Japan to the United States), Latin America (Argentina, Mexico, Chile), Europe (Poland, Hungry), and Asia (China, Japan, India, Bangladesh, Pakistan, Taiwan) (Bhowmik et al. 2015; Shakoor et al. 2015). According to several types of research, As pollution in drinking water is significant, exceeding WHO guidelines, putting 200 million people globally and approximately a hundred million people in Asia at danger of As poison (Bhowmik et al. 2015; Rasool et al. 2015; Shahid et al. 2015; Shakoor et al. 2016). Pakistan, China, Japan, India, Sri Lanka, Germany, Ghana, Senegal, Kenya, Turkey, Algeria, Ethiopia, Uganda, Tanzania, South Africa, New Zealand, Mexico, Thailand, and also Argentina are among the F impacted countries (Rasool et al. 2016; Rafiq et al. 2017). In dry and semi-arid parts of the world, arsenic and F in groundwater are widespread (Farooqi et al. 2007; Rasool et al. 2016).

Lately, the contamination level of As and $\mathrm{F}$ is high in the groundwater of Pakistan (PSQCA, 2017), thereby people who are living in the Indus valley (about 50-60 million) can be affected (Podgorski et al. 2017). Around 95\% of the population in Pakistan depend on groundwater, moreover, they lack awareness and precautionary measure to combat with this problem (Rafiq et al. 2017). Since 1999, UNICEF and PCRWR have recognized for estimation of the quality of drinking water. These agencies have thoroughly sampled groundwater and detected As in the range between (10-200 $\mu \mathrm{g} / \mathrm{L}$ ) and $\mathrm{F}$ in the range (>1.5 mg/L), especially in various areas of Punjab, Pakistan (Toor and Tahir 2009). In addition to them, the urban areas of Lahore, Sheikhupura, Multan, Bahawalpur, and Hyderabad are significantly contaminated by arsenic and Fluoride (WHO 2008; PSQCA 2017). Approximately 61-73 percent of inhabitants in the Sindh province of Pakistan are struggling from chronic toxicity of As and $F$ (Kazi et al. 2009). In another study from District Vehari showed in which 95percent of groundwater was not suitable for drinking indicating huge amount of As and $\mathrm{F}$ in the aquifer of this district that might have adverse impact on human health upon consumption of such water (Shahid et al. 2017).

The District Vehari is a component of Southern Punjab and is situated in the active flood plains of the Indus River in Pakistan. It is a neglected and poor area of Pakistan. In Pakistan, there is limited research focusing on the environmental concern of As and $F$ in drinking water. The objectives of my research are 1) to determine the spatial distribution, characteristics of fluoride or arsenic concentration in drinking water, 2) to elucidate the source identification of fluoride and arsenic contamination using multivariate analysis and possible mechanisms producing high fluoride in the drinking water, and 3) to calculate health risk assessment of fluoride and arsenic intake water for drinking purposes.

\section{Material And Methods}




\subsection{Selection of sampling sites:}

Vehari is a city situated in Pakistan. It is about $100 \mathrm{~km}$ from the historical city Multan. It is seeming to be at a $135 \mathrm{~m}$ altitude. It consists of urban or rural areas. It covers 4,373 square kilometers and has a population of 3.5 million people. We chose the city of Vehari for this research since it is classified as a neglected area with no previous water quality monitoring, mostly near brick kilns. PCRWR, 2006 reported a high concentration of arsenic in Vehari city. We wanted to check out the source of water contamination and also assess of health risk of fluoride and arsenic around brick kilns in Vehari city and their contribution to this pollution.

\subsection{Sampling and pretreatment:}

58 groundwater samples were gathered (Fig. 1). All samples were collected from brick kilns. Water samples were obtained from a variety of sources, including an electric pump, a manual pump, and even a tube well, among others, at various depths (60-200ft). Without filtering, samples were taken in $250 \mathrm{~mL}$ plastic bottles. About 2-3 min pumping, after pumping for water samples were collected to remove the water in pipes and to get samples from ground aquafer. Duplicate samples were collected from one place. One was acidified samples as we had added acid in them and others were non- acidified samples having no acid in them. For cationic analysis, acidified samples were utilized, whereas non-acidified samples have been used for anionic interpretation. The longitude and latitude were acquired on the spot using the (GPS) Global Positioning System. Groundwater analyses have been carried out in the lab of Environmental Science, COMSAT University Islamabad, Vehari Campus. We used a standard method for analysis of different physical and chemical parameters. These samples were wrapped with screw closures and preserved in $4^{\circ} \mathrm{C}$ coolers before being transferred to the laboratory and maintained in coolers to the same degree.

\subsection{Analysis of Groundwater}

$\left(\mathrm{pH} / \mathrm{EC}\right.$ meter W2015) was used to measure the EC, TDS, and $\mathrm{pH}$ of all water samples. AAS was used to identify cations such as $\mathrm{As}^{+} \mathrm{K}^{+}, \mathrm{Na}^{+}, \mathrm{Ca}^{+2}$, $\mathrm{Mn}, \mathrm{Fe}$, and $\mathrm{Mg}^{+2}$, while a UV/VIS Spectrophotometer was used to detect anions such as $\mathrm{SO}_{4}{ }^{-2}$, and $\mathrm{Cl}^{-}$respectively. And for evaluation of anions such as $\mathrm{Cl}^{-}$and $\mathrm{HCO}_{3}{ }^{-}$, the usual approach of titration method was used (APHA, 1998). The ion chromatography method is used to determine the value of fluoride in groundwater.

\subsection{Health Risk Assessment}

\subsubsection{Assessment of Exposure}

A well-known health risk assessment model was applied to know individual health risks exposed to As and $\mathrm{F}^{-}$. Using the equation above, the average daily dosage (ADD) both for As and F-in drinking water was determined:

$\mathrm{ADD}=\mathrm{C} \times \mathrm{IR} \times \mathrm{ED} \times \mathrm{EF} / \mathrm{BW} \times \mathrm{AT}$

Where,

$\mathrm{C}=$ concentration of $\mathrm{As}(\mu \mathrm{g} / \mathrm{L})$ and $\mathrm{F}^{-}(\mathrm{mg} / \mathrm{L})$

ED = exposure duration (assumed 67 years)

$\mathrm{IR}=$ water intake rate $(2 \mathrm{~L} /$ day $)$

BW = body weight $(72 \mathrm{~kg})$ or AT = average lifetime (24,455 days)

$\mathrm{EF}=$ exposure frequency (365 days/year), (Shah et al. 2012; Muhammad et al. 2011; Rasool et al., 2016)

Generally, Health Quotient can be calculated by using the given equation; (USEPA 2005).

$H Q=A D D / R f D$

Where HQ stands for hazard quotient, and It is regarded as a significant health concern if its value exceeds 1 , and while a reference dose (RfD) of As and F- (0.0003 and $0.06 \mathrm{mg} / \mathrm{kg} /$ day) induces toxicity (USEPA 2005).

The following formula was used to determine cancer risk (CR):

$\mathrm{CR}=\mathrm{ADD} \times \mathrm{CSF}$

\subsection{Multivariate Statistical Analysis}

(SPSS) Statistical Package for Social Sciences and Multivariate Statistical Package (MVSP) software was mainly used for some specific purposes including, hierarchical cluster analysis, principal component analysis, and correlation matrix. To make distribution maps of

Page $3 / 12$ 
physicochemical parameters we used Arc GIS and surfer software, fluoride, and arsenic.

\section{Results And Discussion}

\subsection{Physicochemical characteristics}

Different concentrations of physical parameters at the site of city Vehari with standard deviation are represented in Table 1. All the water samples are alkaline $(n=58), \mathrm{pH}$ is measured 7 to 8 with a mean value of 7.802 . The $\mathrm{pH}$ values of samples $(6.5-8.5)$ were equal according to the permissible restriction for drinking water as per guidelines by WHO. The values of EC range from 235 to 2800 ( $\mu \mathrm{S} / \mathrm{cm}$ ) with a mean value of 1357 $(\mu \mathrm{S} / \mathrm{cm})$. The permissible limit of WHO of EC for drinking water is $(400 \mu \mathrm{S} / \mathrm{cm})$ respectively. All the water samples had values more than the WHO limit for EC. Total dissolved solids (TDS) of water samples range from 260 to $1320 \mathrm{mg} / \mathrm{L}$ with a mean value of $665.86 \mathrm{mg} / \mathrm{L}$. That shows that the samples exceeded the normal value as given by WHO (500mg/L). Total hardness (TH) values range from 220 to $1760 \mathrm{mg} / \mathrm{L}$ with a value of mean $686.55 \mathrm{mg} / \mathrm{L}$ were observed in samples. The standard values according to WHO for hardness are known as $500 \mathrm{mg} / \mathrm{L}$ respectively. In samples groundwater, the values increased as $72 \%$ of the permissible limits given by PSI, PSQCA, and $27 \%$ are observed to be within normal limits.

Table 1

Ranges of Arsenic and major ion in drinking water samples of the study area

\begin{tabular}{|llllll|}
\hline Parameters & Sample no & Min & Max & Mean & Std. Deviation \\
\hline $\mathrm{pH}$ & 58 & 7.5 & 8.4 & 7.802 & 0.213 \\
\hline $\mathrm{EC}(\mu \mathrm{s} / \mathrm{cm})$ & 58 & 235 & 2800 & 1357 & 639.22 \\
\hline $\mathrm{TDS}(\mathrm{mg} / \mathrm{L})$ & 58 & 260 & 1320 & 665.9 & 301.3 \\
\hline Hardness (mg/L) & 58 & 220 & 1760 & 686.6 & 319.9 \\
\hline $\mathrm{Cl}-(\mathrm{mg} / \mathrm{L})$ & 58 & 5.3 & 12.45 & 2.12 & 0.84 \\
\hline $\mathrm{HCO}-(\mathrm{mg} / \mathrm{L})$ & 58 & 6.5 & 1769 & 665.9 & 298.65 \\
\hline $\mathrm{Na}+(\mathrm{mg} / \mathrm{L})$ & 58 & 0.3 & 26.3 & 8.76 & 7.137 \\
\hline $\mathrm{K}+(\mathrm{mg} / \mathrm{L})$ & 58 & 0.01 & 1.7 & 0.521 & 0.394 \\
\hline $\mathrm{Mg} 2+(\mathrm{mg} / \mathrm{L})$ & 58 & 2.6 & 20.4 & 5.23 & 0.743 \\
\hline $\mathrm{Ca} 2+(\mathrm{mg} / \mathrm{L})$ & 58 & 0.3 & 14.9 & 2.148 & 2.086 \\
\hline $\mathrm{Ba}(\mathrm{mg} / \mathrm{L})$ & 58 & 4 & 37.7 & 20.24 & 6.281 \\
\hline $\mathrm{As}(\mu \mathrm{g} / \mathrm{L})$ & 58 & 0.33 & 11.12 & 2.74 & 2.309 \\
\hline $\mathrm{SO} 42-(\mathrm{mg} / \mathrm{L})$ & 58 & 0.097 & 2.244 & 0.856 & 0.495 \\
\hline $\mathrm{Mn}(\mathrm{mg} / \mathrm{L})$ & 58 & 0.0217 & 0.172 & 0.682 & 0.318 \\
\hline $\mathrm{F}(\mathrm{mg} / \mathrm{L})$ & 58 & 0.68 & 9.69 & 2.59 & 1.707 \\
\hline $\mathrm{Fe}(\mathrm{mg} / \mathrm{L})$ & 58 & 0.024 & 0.312 & 0.078 & 0.006 \\
\hline
\end{tabular}

Bicarbonates $\left(\mathrm{HCO}_{3}{ }^{-}\right)$ranges within $6.5-1769 \mathrm{mg} / \mathrm{L}$ with a mean value of $665.85 \mathrm{mg} / \mathrm{L}$. The greatest $\mathrm{HCO}_{3}{ }^{-}$values at sample location $23(\mathrm{~S})$ are recorded with the value of $1769 \mathrm{mg} / \mathrm{L}$, respectively. The $\mathrm{Cl}$ - ranges from 5.3 to 12.45 with mean values 2.12, which lies within WHO standard limits. Sulfate concentrations in samples ranged from 0.97 to $2.244 \mathrm{mg} / \mathrm{L}$, with a mean value of $0.856 \mathrm{mg} / \mathrm{L}$. According to the WHO, the maximum sulfate concentration in drinking water is $250 \mathrm{mg} / \mathrm{L}$. Sodium $\left(\mathrm{Na}^{+}\right)$, which ranged from 0.3 to $26.3 \mathrm{mg} / \mathrm{L}$ including an average value of $8.757 \mathrm{mg} / \mathrm{L}$, was found to be within the WHO permitted limit of $200 \mathrm{mg} / \mathrm{L}$ for sodium ions in drinking purposes. Ca ${ }^{+2}$ values vary from 0.4 to 14.9 $\mathrm{mg} / \mathrm{L}$, with $2.148 \mathrm{mg} / \mathrm{L}$ being the average. Calcium values of less than $60 \mathrm{mg} / \mathrm{L}$ are considered soft. The content of magnesium ( $\mathrm{Mg}{ }^{+2}$ ) in the water varies from 2.6 to $20.4 \mathrm{mg} / \mathrm{L}$, with a mean value of $5.23 \mathrm{mg} / \mathrm{L}$. According to WHO standards, the maximum amount of magnesium in water is $150 \mathrm{mg} / \mathrm{L}$. All the values of $\mathrm{Mg}$ ions for drinking water samples of city Vehari were reported as less than the permissible value of magnesium.

The normal intake of potassium for grownups (19-> 70 years of age) is $4.7 \mathrm{~g} /$ day. Barium concentration ranges from 4 to 37.5 with a mean value of $20.236 \mathrm{mg} / \mathrm{l}$. All the groundwater samples values exceeded the WHO permissible limit ( $2.0 \mathrm{mg} / \mathrm{l})$. The Fe and Mn concentration ranges from 0.024 to 0.314 and 0.022 to 0.172 , respectively. And $61 \%$ samples increased Fe and Mn values from WHO standard limits. As concentration ranges from 0.330 to $11.120 \mu \mathrm{g} / \mathrm{L}$ with a mean value of $2.73 \mu \mathrm{g} / \mathrm{L}$, higher than the WHO recommended permissible level of As in groundwater (10 
$\mu \mathrm{g} / \mathrm{L}$ ). The total value of fluoride in drinking water is $2.598 \mathrm{mg} / \mathrm{L}$ as its concentration ranges are 0.680 to $9.690 \mathrm{mg} / \mathrm{L}$, respectively. WHO standards for fluoride in groundwater are $1.5 \mathrm{mg} / \mathrm{L}$. All the values of fluoride in drinking water were higher than the permissible limit according to WHO standards.

In the majority of the groundwater samples, constituents including $\mathrm{Cl}^{-}, \mathrm{K}^{+}, \mathrm{Ca}^{2+}$, and $\mathrm{Mg}^{2+}$ were found in the acceptable drinking water levels. The remainder of the elements, such as $\mathrm{HCO}_{3}{ }^{-}, \mathrm{Fe}, \mathrm{Ba}$, and $\mathrm{Mn}$, were crossed the safe drinking water levels in all of the groundwater samples.

Although not considered toxic elements such as $\mathrm{SO}_{4}{ }^{2-}, \mathrm{Ca}^{2+}, \mathrm{Na}^{+}, \mathrm{K}^{+}, \mathrm{Cl}^{-}$, and $\mathrm{Mg}^{+2}$ may cause the water to become undrinkable owing to persistent taste and color (USEPA 2005). Groundwater from different types of rocks such as sandstone, shales, limestone, may contain higher Mn and Fe concentrations (Rasool et al. 2015; Murtaza et al. 2019). Higher concentrations of Fe and Mn in the study area were due to iron sulfide mineral rocks (Nguyen et al. 2009). The weathering of carbonaceous rocks and agricultural activities might be a cause of higher concentration of HCO3- in groundwater (Ramkumar et al. 2010; Rasool et al. 2016).

The concentration of arsenic and fluoride is summarized in Table 1. The presence of significant levels of F-, and As, in the groundwater, shows that air pollution from brick industries distributed around the research area is a source of these elements (Farooqi et al. 2007). Toxic elements such as As and $\mathrm{F}$ are known to escape when mineralized coal is burned ${ }^{-}$(Finkelman et al. 2002). The results of the current study were in covenant with the study of (Farooqi et al. 2007). The results of both previous and present studies suggest that the common source for the coincidental occurrence of both these elements i.e., As and $\mathrm{F}^{-}$in the groundwater samples might be the coal combustion at brick factories and fertilizer activity as the brick factories are abundantly located in the current study area, where coal combustion is commonly practiced.

\subsection{Spatial distribution of fluoride concentration}

In all of the groundwater samples, the F and As concentration above WHO allowed levels and its regional distribution is depicted in (Fig. 2). Concentrations of As and F were found higher in groundwater samples collected around brick kilns. Figure 2 represents the spatial distribution of As and $F$ in groundwater samples. According to distribution maps the maximum concentrations of As and $F$ was found from east to west of district Vehari (Fig. 2). The presence of As and F in the groundwater samples suggested that both elements have a common source of contamination because a positive correlation was observed among As and F, respectively. The occurrence of high As and $F$ in the groundwater suggests that their source might be air pollutants that originate from coal combustion (Finkelman et al. 2002), especially at brick factories, which are common in the study area (Farooqi et al., 2007; Rasool et al., 2020). Our results are similar to the findings of Rasool et al., (2015) and Farooqi et al., (2007), which reported increased $\mathrm{F}$ and As concentrations in groundwater in the areas of East Punjab, Pakistan. The fluoride and arsenic concentration was substantially less than in previous investigations in Sialkot (Ullah et al. 2009), D.G Khan (Malana and Khosa 2011).

\subsection{Arsenic and fluoride Health Risk Assessment}

We asked different questions for information to the people who live near the brick kilns such as age, sex, health, and drinking water resources. They used groundwater along with the surface water for drinking and domestic purposes. Human health would become acquainted with selected elements by three major behaviors: direct ingestion, inhaling, and dermal absorption through the skin; nonetheless, ingestion and dermal absorption are the most prevalent routes for drinking water disclosure (USEPA 2005; Wu et al. 2010). The final results of the average daily dose (ADD) in the Vehari area show that people have consumed drinking water contaminated with As and $\mathrm{F}^{-}$as shown in Table (2). The ADD values of As and $\mathrm{F}$ in Vehari drinking water $\left(7.500 \times 10^{-3}-3.6 \times 10^{-5} \mathrm{mg} / \mathrm{kg} /\right.$ day) and $\left(8.400 \times 10^{-2}-4.3 \times 10^{-6} \mathrm{mg} / \mathrm{kg} /\right.$ day) respectively was much higher as compared to other studies that occurred in different areas of Pakistan $\left(0.00-5.56 \times 10^{-7} \mathrm{mg} / \mathrm{kg} / \mathrm{day}\right)$. In my study area, the calculated HQ through intake of As and F contamination in drinking water was found highest value (87.6) and (96.7) in the Vehari area. About $90 \%$ of people in the Vehari area around brick kilns were used water for drinking purposes and other household purposes and considered as at higher risk as compared to other cities.

Large ADD ratios of As and $\mathrm{F}$ - in groundwater can be linked to $\mathrm{Pb}-\mathrm{Zn}$ sulfide mineralization, effluent organizations and mafic and ultramafic bed rocks harboring chromite deposits, agricultural operations, according to groundwater quality (Rasool et al. 2020). In the case of the current investigation, the human risk assessment of As and F- achievable THQ demand has a level of hazardous adverse health risk (Table 2). THQ of selected elements were discovered in the sequence of F->As through groundwater consumptions, respectively, according to on water quality. When contrasted, the THQ catalogs for As and F- revealed a risk to the local people (Khan et al 2008). THQ indices of As and F-, on the other hand, tend to be higher than any of those disclosed in groundwater (Kavcar et al. 2009; Rasool et al. 2015a). The evidence in (Table 2) showed that that the value of THQ in this research was not in the safe limits (THQ > 1), indicating a health hazard in this area (Muhammad et al. 2011). The current research in terms of health perspectives, extremely important because it indicates the health hazard to the population from As and $\mathrm{F}$ consumption in drinking water. When compared to approach, approximately $60 \%$ of people in study areas were using drinking water and household activities, and thus considered at risk of becoming infected to As and F- metals (USEPA 2010; Rasool et al. 2015a). When compared to the approach, 40\% of people in both areas showed medium risk (USEPA 2010). The findings demonstrate that the research study has a high degree of As and Fcontamination, making it unsafe for drinking and other domestic uses. In addition to high levels of As and F in groundwater, other issues arise, such as poverty, malnutrition, inadequate medical treatment, and the presence of other toxicants in drinking water and food, all of which can have 
a synergistic influence on people's health (Arain et al. 2009; Baig et al. 2011; Rasool et al. 2020). This is a troubling situation in the research area that requires immediate attention to save the health of those who are at risk.

Table 2

Arsenic and Fluoride ranges of $A D D, H Q$ and $C R$ in drinking water of Vehari

\begin{tabular}{|lllll|}
\hline Parameters & Min & Max & Mean & STD \\
\hline As(mg/L) & 0.33 & 11.12 & 2.73274 & 2.309 \\
\hline ADD $(\mathrm{mg} / \mathrm{Kg}$ Day $)$ & 0.0086 & 0.0189 & 0.657 & 0.562 \\
\hline $\mathrm{HQ}$ & 2.8 & 87.6 & 26.7 & 38.5 \\
\hline $\mathrm{CR}$ & 0.0056 & 0.78 & 0.093 & 0.086 \\
\hline $\mathrm{F}(\mathrm{mg} / \mathrm{L})$ & 0.68 & 9.69 & 2.598 & 1.707 \\
$\mathrm{ADD}(\mathrm{mg} / \mathrm{Kg}$ Day $)$ & 0.098 & 0.0698 & 0.963 & 0.872 \\
\hline $\mathrm{HQ}$ & 4.6 & 96.7 & 42.2 & 54.7 \\
\hline $\mathrm{CR}$ & 0.009 & 0.93 & 0.64 & 0.098 \\
\hline
\end{tabular}

\subsection{Multivariate Statistical Analysis}

\subsubsection{Source discernment of As and $\mathrm{F}^{-}$}

Multivariate analysis was used to distinguish between different sets of experimental factors as a tracer of natural and anthropogenic origins. For the source identification of As, F-, and physicochemical characteristics, cluster analysis (CA), correlation matrices, and principal component analysis (PCA) have been proven to be helpful techniques (Mico et al. 2006; Muhammad et al. 2011). The following are correlation matrices for all study parameters measured in groundwater samples (Table 3). The correlation matrices demonstrate that several physicochemical parameter pairs have a substantial positive association in groundwater samples like EC- TDS $(r=0.823), \mathrm{TDS}^{-} \mathrm{Ca}(\mathrm{r}=0.543), \mathrm{HCO}_{3}{ }^{-}-\mathrm{Mg}(\mathrm{r}=0.425), \mathrm{Mg}^{-}$ $\mathrm{Na}(\mathrm{r}=0.359), \mathrm{Mg}^{-}-\mathrm{As}(\mathrm{r}=0.283), \mathrm{Na}^{+}-\mathrm{SO} 4(\mathrm{r}=0.456), \mathrm{As}-\mathrm{F}(\mathrm{r}=0.992), \mathrm{HCO} 3-\mathrm{Na}(\mathrm{r}=0.345), \mathrm{SO}_{4}{ }^{2-}-\mathrm{Mg}^{2+}(\mathrm{r}=0.42), \mathrm{Mn}^{-} \mathrm{As}(\mathrm{r}=0.313)$. Similarly, some pairs show significant negative correlations such as Na-K ( $r=-0.454)$, and SO4 $-K(r=-0.412)$, respectively. The correlation matrix reveals that two variables have the same source and therefore are correlated, with the primary source of these correlations being anthropogenic activities such as agricultural, commercial, landfill, coal burning, and home waste (Rasool et al. 2020). In the current study As and $\mathrm{F}$ show a strong positive correlation, which means both have a similar source of contamination that is brick kilns. The high concentration of $\mathrm{F}$ and As in water samples may be the application of fertilizer, rock-water interaction, acid rain, coal combustion, mining waste, and industrial waste (Khan et al. 2012; Rasool et al. 2020). 
Table 3

Pearson correlation results for the physicochemical parameters of drinking water

\begin{tabular}{|c|c|c|c|c|c|c|c|c|c|c|c|c|c|c|}
\hline Parameters & $\mathrm{pH}$ & $\mathrm{EC}$ & TDS & $\mathrm{Ca}$ & $\mathrm{Mg}$ & $\mathrm{Cl}$ & so4 & $F$ & $\mathrm{HCO} 3$ & $\mathrm{Na}$ & K & Mn & $\mathrm{Fe}$ & As \\
\hline $\mathrm{pH}$ & 1 & & & & & & & & & & & & & \\
\hline EC & 0.24 & 1 & & & & & & & & & & & & \\
\hline TDS & 0.51 & 0.823 & 1 & & & & & & & & & & & \\
\hline $\mathrm{Ca}$ & 0.279 & 0.436 & 0.543 & 1 & & & & & & & & & & \\
\hline $\mathrm{Mg}$ & 0.4 & -0.176 & -0.139 & 0.472 & 1 & & & & & & & & & \\
\hline $\mathrm{Cl}$ & 0.484 & 0.465 & 0.163 & 0.174 & 0.085 & 1 & & & & & & & & \\
\hline SO4 & 0.072 & 0.176 & 0.196 & 0.049 & 0.42 & -0.171 & 1 & & & & & & & \\
\hline $\mathrm{F}$ & 0.142 & 0.219 & 0.219 & 0.186 & 0.0567 & 0.124 & 0.167 & 1 & & & & & & \\
\hline $\mathrm{HCO} 3$ & 0.039 & 0.227 & 0.228 & 0.214 & 0.425 & -0.017 & 0.084 & 0.252 & 1 & & & & & \\
\hline $\mathrm{Na}$ & 0.059 & 0.234 & 0.639 & 0.117 & 0.359 & 0.282 & 0.456 & 0.242 & 0.345 & 1 & & & & \\
\hline K & 0.084 & -0.184 & 0.345 & -0.086 & -0.229 & -0.133 & -0.412 & -0.273 & -0.144 & -0.454 & 1 & & & \\
\hline $\mathrm{Mn}$ & 0.006 & 0.191 & 0.555 & 0.094 & 0.245 & -0.102 & 0.033 & 0.021 & 0.101 & 0.024 & 0.123 & 1 & & \\
\hline $\mathrm{Fe}$ & 0.137 & 0.226 & 0.224 & 0.09 & 0.004 & 0.125 & 0.092 & -0.081 & 0.041 & 0.325 & 0.234 & 0.096 & 1 & \\
\hline As & 0.049 & 0.159 & 0.345 & 0.054 & 0.283 & -0.012 & 0.389 & 0.922 & 0.266 & 0.283 & -0.262 & 0.313 & 0.026 & 1 \\
\hline
\end{tabular}

The co-relationship among As and $\mathrm{F}$ and physicochemical parameters were explained by a dendrogram of $\mathrm{CA}$ in groundwater water samples of the study area (Fig. 3). A dendrogram is made up of a similarity level at which explanations are merged (Chen et al. 2007). The CA technique is useful in contributing to the steady categorization of subsurface waters in the entire area and may be as effective in spatial water quality assessment as the entire network. Other researchers have mentioned the same thing (Arain et al. 2009; Rasool et a. 2020).

Therefore, drinking water samples were grouped into a cluster (G1), cluster (G2), and cluster (G3) respectively (Fig. 3). The G1 includes Na, SO4, K, $\mathrm{Ca}, \mathrm{Mg}$, As, and F, suggesting similar sources of all elements, mostly anthropogenic such as coal burning, agricultural waste, mining waste, and natural causes (Bityukova and Petersell 2020; Rasool et al. 2020). Similarly, G2 includes pH, Fe, and Ba, demonstrating that they were originated from human activities and parent rock material (Ahmed et al. 2004; Rasool et al. 2016). The G3 contributes parameters such as Mn, TDS, Cl, EC, and TDS, which might be originated natural, and anthropogenic materials. Likewise, outcomes have been documented previously (Arain et al. 2009; Rasool et al. 2015). The drinking water clustering analysis results of this study were compared and found similar results to those reported by Qurat-ul- Ain et al. (2017) and Rasool et al. (2020).

The qualitative information about clustering behavior was extracted using PCA (Table 4). The association and grouping were further indicated by PCA with five factors having a total variance of $703.97 \%$, respectively (Table 4). F1 contributed $24 \%$ to the total variance with high loading on EC $(r=0.713)$, SO4 $(r=0.376)$, TDS $(r=0.522), \mathrm{Ba}(r=0.732), \mathrm{HCO}(r=0.687)$, and $\mathrm{Na}(r=0.682)$, respectively. The sources of factor one parameters could be anthropogenic and geogenic due to weathering of the sulfide's bearing minerals and acidic rocks (Faroogi et al. 2007; Khan et al. 2012). F2 determined $18.65 \%$ of the total variance with high loading on $\mathrm{Cl}(r=0.584)$, and $\mathrm{K}(\mathrm{r}=0.525)$, suggesting anthropogenic sources such as agricultural activities. F3 and F4 determined $15 \%$ and $13 \%$ with high loadings on $\mathrm{Fe}(r=0.657)$, and $\mathrm{Mn}(\mathrm{r}=0.851)$ which is due to the local geochemistry of the area, influenced by weathering of mafic and ultramafic rocks (Shah 2000; Rasool et al. 2020). F5 contributed 10\% to the total variance with a high loading on $F(r=0.775)$ and $A s(r=0.631)$, respectively. High levels of As and $F$ have shown the influence of agriculture, burning of coal, industrial activities, weathering of rocks, and mining waste into the aquifer (Shakoor et al. 2015; Rasool et al. 2016). Similarly in the study area occurrence of $\mathrm{F}$ and As in the groundwater might be coal combustion and brick factories which are common in the study area. 
Table 4

Factor loading for selected physio-chemical parameters in groundwater $(\mathrm{n}=$

58)

\begin{tabular}{|c|c|c|c|c|c|}
\hline Parameters & Factor 1 & Factor 2 & Factor 3 & Factor 4 & Factor 5 \\
\hline $\mathrm{pH}$ & -0.52 & 0.14 & 0.123 & -0.456 & 0.312 \\
\hline $\mathrm{EC}$ & 0.713 & 0.65 & 0.252 & -0.23 & -0.112 \\
\hline TDS & 0.522 & 0.64 & 0.259 & -0.232 & -0.104 \\
\hline $\mathrm{Ca}$ & 0.442 & 0.169 & -0.252 & 0.151 & -0.594 \\
\hline $\mathrm{Mg}$ & 0.889 & 0.006 & 0.035 & 0.18 & -0.106 \\
\hline $\mathrm{Cl}$ & -0.086 & 0.584 & 0.233 & -0.009 & 0.675 \\
\hline $\mathrm{SO}_{4}$ & 0.376 & -0.423 & 0.373 & -0.222 & 0.004 \\
\hline $\mathrm{Ba}$ & 0.732 & 0.043 & -0.538 & 0.008 & 0.139 \\
\hline $\mathrm{HCO} 3$ & 0.687 & 0.047 & -0.447 & 0.139 & 0.259 \\
\hline $\mathrm{Na}$ & 0.682 & -0.521 & -0.072 & -0.192 & 0.029 \\
\hline K & -0.424 & 0.525 & -0.066 & 0.479 & 0.045 \\
\hline $\mathrm{Mn}$ & 0.254 & -0.038 & 0.221 & 0.851 & -0.169 \\
\hline $\mathrm{Fe}$ & 0.142 & 0.339 & 0.657 & 0.131 & 0.003 \\
\hline $\mathrm{F}$ & 0.023 & -0.302 & 0.775 & 0.093 & 0.775 \\
\hline As & 0.473 & -0.318 & 0.199 & 0.32 & 0.631 \\
\hline Eigenvalues & 3.605 & 2.048 & 1.65 & 1.21 & 1.078 \\
\hline Variability (\%) & 24.033 & 18.65 & 15.02 & 13.08 & 10.18 \\
\hline Cumulative (\% & 24.033 & 32.68 & 63.7 & 68.79 & 73.97 \\
\hline \multicolumn{6}{|c|}{ Values of dominant element in each factor is reported in bold. } \\
\hline n means numl & f cam & & & & \\
\hline
\end{tabular}

\section{Conclusions}

Results of this study indicated that As and F concentration exceeded the values given by WHO. People used groundwater for drinking purposes in most of the areas. The concentration of As and F in groundwater around the brick kilns was slightly higher as compared to other areas. This is due to different anthropogenic activities or weathering of rocks and volcanic eruption etc. Phosphate fertilizer manufacturing plants, refineries, burning coal, steel manufacture, and brick kilns are the main anthropogenic sources. A higher amount of F and As in groundwater may cause severe diseases. Such as caused teeth and bone diseases due to high fluoride amounts in water. Ingestion of inorganic arsenic can induce skin cancer, while inhalation of inorganic arsenic can cause severe lung cancer. Excessive As levels in drinking water can inflict arsenical cobalt, which ate away at the skin cells of employees at the site. It can be concluded that the fuel used in brick kilns or their residue may increase the level of $\mathrm{F}$ and As in groundwater and also increase the health risk in the people working there, so we should remediate the water pollution by using different techniques. As and $\mathrm{F}$ levels are incessantly increasing in the study area, making it unsuitable for drinking, which is a risky situation and desires immediate, cost-effective treatment technologies to safe health of people at risk. Furthermore, an awareness program about $\mathrm{F}$ and As pollution in groundwater and its associated health risk is necessary for such kind of area.

\section{Declarations}

\section{Acknowledgments}

We strongly acknowledge the Pakistan Geological Survey and higher education commission for funding projects for research. We are thankful to our friends and teachers, who helped to improve our MS.

\section{Conflict of Interest}


There are no conflicts of interest mentioned by all the writers.

\section{Authors Contributions}

Rukhsar Fatima and Atta Rasool have initially prepared draft. Allah Wasaya has helped to calculate the health risk assessment and make map for sampling point. Muhammad Akaram help in statistical analysis and finally revised whole manuscript carefully.

\section{Ethical Approval}

In current study living organisms (for example, human, animals etc) data not used. For risk assessment, we used information collected from the residents of study area.

\section{Consent to Publish}

Not into open access

\section{Consent to Participate}

All authors contribute equally in submitted manuscript.

\section{Funding}

No funding provided for this research.

\section{Availability of data and materials}

Samples collected from field, then analysis done in labs. All data is accurate and original.

\section{References}

1. Arain M, Kazi T, Baig J, Jamali M, Afridi H, Shah A, Jalbani N, Sarfraz R (2009) Determination of arsenic levels in lake water sediment and foodstuff fromselected area of Sindh Pakistan: estimation of daily dietary intake. Food Chem.Toxicol. 47: $242-248$.

2. Baig JA, Kazi TG, Arain MB, Afridi HI, Kandhro GA, Sarfraz RA, Jamal MK, Shah AQ (2009) Evaluation of arsenic and other physico chemicalparameters of surface and groundwater of Jamshoro Pakistan. J. Hazard.Mater. 166: 662-669.

3. Khalid S (2019) "Using Urinary Fluoride And Dental Fluorosis As Biomarkers Of Fluoride Exposure In Brick Kiln Workers In Balochistan Pakistan." Fluoride 52: 415-425.

4. Khalid S, Mansab S (2015) "Effect of fluorides on air water soil and vegetation in peripheral areas of Brick Kiln of Rawalpindi." Pak. J. Botany 47: 205-209.

5. Bhowmik AK, Alamdar A, Katsoyiannis I, Shen H, Ali N, Ali SM, Bokhari H, Schäfer RB, Eqani SAMAS (2015) Mapping human health risks from exposure to trace metal contamination of drinking water sources in Pakistan. Science of Total Environment. 538: 306-316.

6. Shakoor M B, Niazi NK, Bibi I, Rahman MM, Naidu R, Dong Z, Shahid M, Arshad M (2015) Unraveling health risk and speciation of arsenic from groundwater in rural areas of Punjab Pakistan. International Journal of Environmental Research and Public Health. 12: 12371-12390.

7. Farooqi A, Masuda H, Kusakabe M, Naseem M, Firdous N (2007) Distribution of highly arsenic and fluoride contaminated groundwater from east Punjab Pakistan and the controlling role of anthropogenic pollutants in the natural hydrological cycle. Geochem J. 41: $213-234$.

8. Farooqi A, Masuda H, Siddiqui R, Naseem M (2009) Sources of arsenic and fluoride in highly contaminated soils causing groundwater contamination in Punjab Pakistan. Arch Environ Con Tox. 56: 693-706.

9. Guo JX, Hu L, Yand PZ, Tanabe K, Miyatalre M, Chen Y (2007) Chronic arsenic poisoning in drinking water in Inner Mongolia and its associated health effects. J. Environ. Sci. Health A 42: 1853-1858.

10. Jankong P, Chalhoub C, Kienzl N, Goessler W, Francesconi KA, Visoottiviseth P (2007) Arsenic accumulation and speciation in freshwater fish living in arsenic-contaminated waters. Environ Chem. 4: 11-17.

11. Rafique T, Naseem S, Bhanger MI, Usmani TH (2008) Fluoride ion contamination in the groundwater of Mithi sub-district the Thar Desert Pakistan. Environ. Geol. 56: 317-326. 
12. Rasool A, Xiao TF, Baig ZT, Masood S, Mostofa KMG, Iqbal M (2015) Arsenic in groundwater and its health risk assessment in drinking water of Mailsi Punjab Pakistan. Hum Ecol Risk Assess. I 22: 187-202.

13. Bityukova L, Petersell V (2010) Chemical composition of bottled mineral water in Estonia. J Geoch Explorat. 1073: $238-244$.

14. Qurat-ul-Ain FA, Sultana J, Masood N (2017) Arsenic and fluoride co-contamination in shallow aquifers from agricultural suburbs and an industrial area of Punjab Pakistan: Spatial trends sources and human health implications. Toxicology and Industrial Health. 33: 655-672.

15. Chen K, Jiao JJ, Huang J, Huang R (2007) Multivariate statistical evaluation oftrace elements in groundwater in a coastal area in Shenzhen China. Environ. Pollut. 147: 771-780.

16. Khan S, Shahnaz M, Jehan N, Rehman S, Shah MT, Din I (2012) Water qualityand human health risk in Charsadda district Pakistan. J. Clean. Prod. 10: 10-16.

17. Mico C, Recatala L, Peris M, Scanchez J (2006) Assessing heavy metal sources inagricultural soils of European Mediterranean area by multivariate analysis. Chemosphere. 65: 863-872.

18. Rasool A, Xiao T, Baig ZT, Masood S, Mostofa KMG, Iqbal M (2015) Co-occurrence of arsenic and fluoride in the groundwater of Punjab Pakistan:source discrimination and health risk assessment. Environ. Sci. Pollut. Res. 22: 19729-19746.

19. Kavcar P, Sofuoglu A, Sofuoglu SC (2009) A health risk assessment for exposureto trace metals via drinking water ingestion pathway. Int. J. Hyg. Environ. Health. 2: 216-227.

20. US-EPA 2010. Risk-based Concentration Table. United State Environmental Protection Agency Philadelphia Pa and Washington DC Available http://www.epa.gov/reg3hwmd/risk/human/index.htm.

21. Rasool A, Farooqi A, Xiao T, Masood S, Kamran MA (2016) Elevated levels of arsenic and trace metals in drinking water of Tehsil Mailsi Punjab Pakistan. Journal of Geochemical Exploration. 169: 89-99.

22. Muhammad S, Shah MT, Khan S (2011) Health risk assessment of heavy metalsand their source apportionment in drinking water of Kohistan region northernPakistan. Microchem. J. 98: 334-343.

23. Shahid N, Zia Z, Shahid M, Faiq Bakhat H, Anwar S, Mustafa Shah G, Rizwan Ashraf M (2015) Assessing Drinking Water Quality in Punjab Pakistan. Polish Journal of Environmental Studies 24: 2597-2606.

24. Shakoor MB, Niazi N K, Bibi I, Murtaza G, Kunhikrishnan A, Seshadri B, Shahid M, Ali S, Bolan NS, Ok YS (2016) Remediation of arseniccontaminated water using agricultural wastes as biosorbents. Critical Reviews of Environ Science and Technol. 46: 467-499.

25. Rafiq M, Shahid M, Shamshad S, Khalid S, Niazi NK, Abbas G, Saeed MF, Ali M, Murtaza B (2017) A comparative study to evaluate efficiency of EDTA and calcium in alleviating arsenic toxicity to germinating and young Vicia faba L. seedlings. Journal of Soils and Sediments. 1-11.

26. PSQCA 2017. Pakistan Standards Quality Control Authority Islamabad Pakistan.

27. Podgorski JE, Eqani SAMAS, Khanam T, Ullah R, Shen H (2017) Extensive arsenic contamination in high-pH unconfined aquifers in the Indus Valley. Science Advances 3 e1700935. DOI: 10.1126/sciadv.1700935 3.

28. Murtaza B, Shah NS, Sayed M, Khan JA, Imran M, Shahid M, Khan ZUH, Ghani A Murtaza G, Muhammad N et al. (2019) Synergistic effects of bismuth coupling on the reactivity and reusability of zerovalent iron nanoparticles for the removal of cadmium from aqueous solution. Sci Total Environ. 669: 333-341.

29. Nguyen VA, Bang S, Viet PH, Kim KW (2009) Contamination of groundwater and risk assessment for arsenic exposure in Ha Nam province Vietnam. Environ Int. 353: 466-472.

30. Toor I, Tahir S (2009) Study of arsenic concentration levels in Pakistani drinking water. Polish Journal of Environmental Studies. 18 : $907-912$.

31. WHO (2008) Guidelines for drinking water quality. In: Recommendations. WorldHealth Organization; 3rd ed.vol. 1 Geneva.

32. Kazi TG, Arain MB, Baig JA, Jamali M K, Afridi HI, Jalbani N. et al (2009) The correlation of arsenic levels in drinking water with the biological samples of skin disorders. Science of the Total Environment. 407: 1019-1026.

33. Shahid M, Khalid M, Dumat C, Khalid S, Niazi NK, Imran M, Bibi I, Ahmad I, Hammad HM, Tabassum RA (2017) Arsenic Level and Risk Assessment of Groundwater in Vehari Punjab Province Pakistan. Exposure and Health. 1-11.

34. USEPA (2005) Guidelines for Carcinogen Risk Assessment; EPA/630/ P-03/001F; Risk Assessment Forum: Washington DC USA.

35. Ramkumar M, St€uben D, Berner Z, Schneider J (2010) 87Sr/86Sr anomalies in Late Cretaceous-Early Tertiary strata of the Cauvery basin south India: constraints on nature and rate of environmental changes across K-T boundary. J Earth Syst Sci. 1191:1-17.

36. Finkelman RB, Orem W, Castranova V, Tatu CA, Belkin HE, Zheng B, Lerch HE, Maharaj SV, Bates AL (2002) Health impacts of coal and coal use: possible solutions. Int J Coal Geol. 50: 425-443.

37. Rasool A, Muhammad S, Shafeequec M Ahmad I, Al-Misnede FA, El-Serehye HA, Ali S, Murtazaa B, Sarwar A (2020) Evaluation of arsenic contamination and potential health risk through water intake in urban and rural areas. HUMAN AND ECOLOGICAL RISK ASSESSMENT: AN INTERNATIONAL JOURNAL. 6: 1655-1670.

38. Ullah R, Malik RN, Qadir A (2009) Assessment of groundwater contamination in an industrial city Sialkot Pakistan. Afr J Environ Sci Technol. 3: $429-446$. 
39. Malana MA, Khosa MA (2011) Groundwater pollutionwith special focus on arsenic Dera Ghazi Khan-Pakistan. J Saudi Chem Soc. 15 : $39-47$. 40. Wu L, Xu JL, Chang AC, Zhang Y (2010) Impact of long-term reclaimed wastewater irrigation on agricultural soils: a preliminary assessment. J Hazard Mater. 183: 780-786.

\section{Figures}

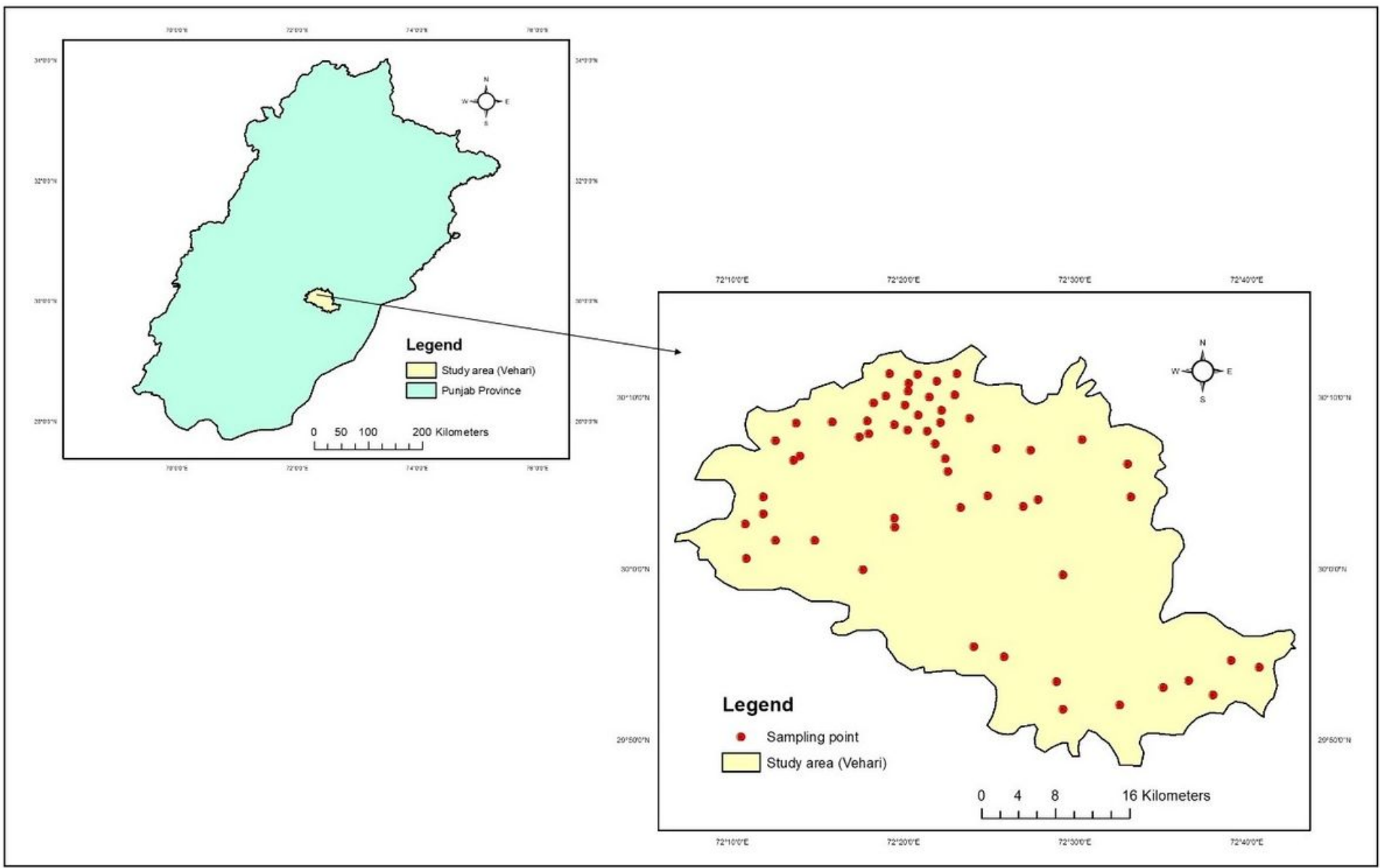

Figure 1

Maps showing location point of the study area
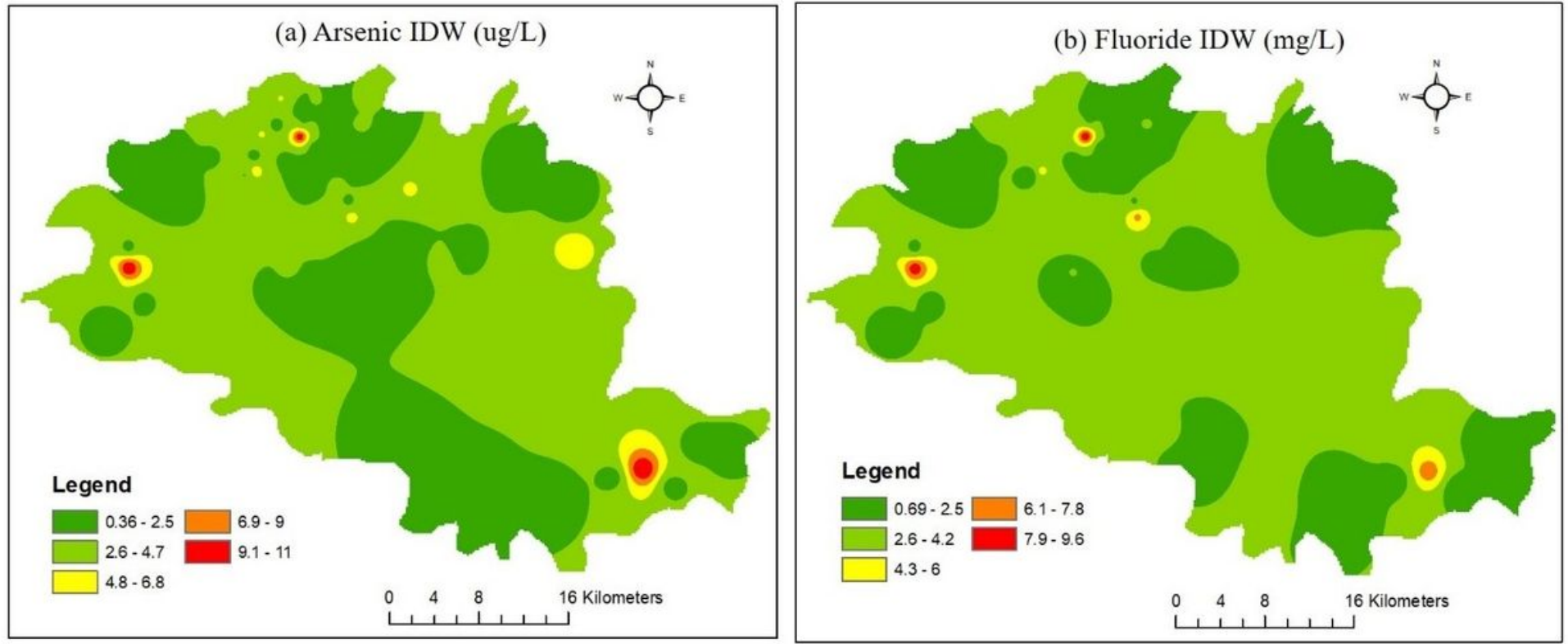

Page $11 / 12$ 
Figure 2

Spatial distribution of arsenic and fluoride

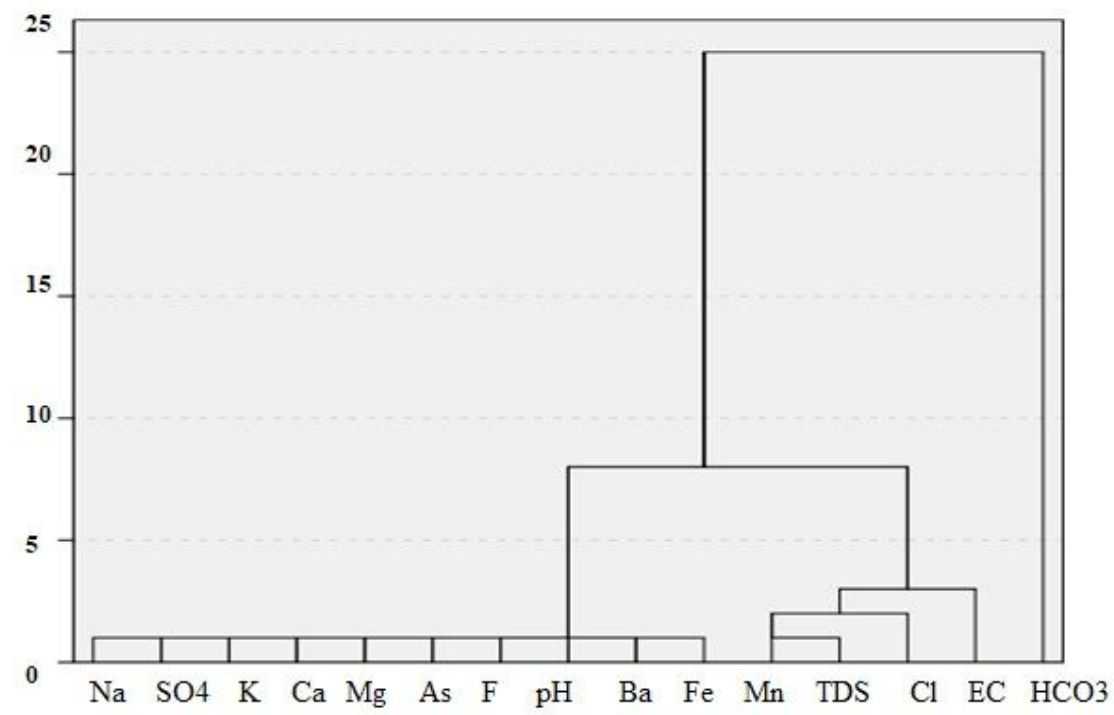

Figure 3

Dendrogram denoted clusters of water samples collected from Vehari to distribute As and physicochemical parameters 